\title{
Una deuda que saldar
}

Dr. Miguel Capomassi

Jefe del Servicio de Miembro Superior, Instituto de Ortopedia y Traumatología

"Dr. Jaime Slullitel", Rosario, Argentina

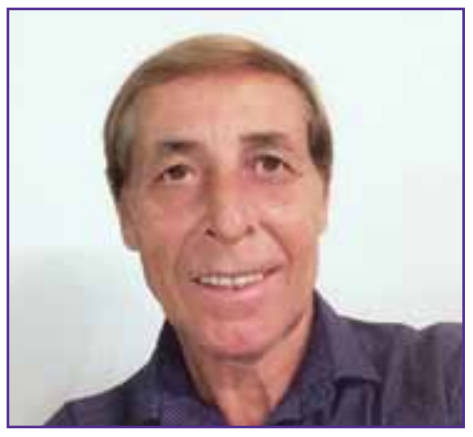

$\mathrm{H}$ istóricamente nuestra Asociación se ha caracterizado por la búsqueda denodada e incesante de un nivel científico que se corresponda con los máximos estándares exigidos por la comunidad médica internacional. Sus progenitores marcaron el camino, hombres que han puesto con trabajo y talento a la Cirugía de la Mano Argentina en un sitial de privilegio en el mundo entero.

Sin embargo, desde su gestación en 1974, apenas existe el antecedente de una revista científica difundida por la Asociación Argentina de Cirugía de la Mano en dicha década, iniciativa que se abortó, por causas diversas, en su segundo suplemento. Desde entonces, nuestra Asociación no cuenta con un órgano de divulgación propio que permita canalizar las inquietudes científicas de nuestros asociados. Este objetivo, que constituye la esencia misma del ejercicio y la práctica médica, comienza hoy a presentar visos de realidad.

A partir de la iniciativa propuesta por la Comisión Directiva encabezada por su Presidente, el Dr. Enrique Pereira, y el trabajo serio y responsable de un grupo de especialistas jóvenes que integran el Comité Editorial se ha formalizado la creación de una publicación propia, cancelando así una vieja deuda de nuestra Asociación y marcando, sin dudas, un hito histórico en la vida de la AACM.

Dicha publicación será vehiculizada en su etapa inicial a través de la Revista de la Asociación Argentina de Ortopedia y Traumatología, órgano de gran relevancia y penetración en Latinoamérica. Es una oportunidad única que debe estimularnos a ejercitar la gimnasia de la publicación y divulgación médica, honesta y altruista. De nosotros depende proyectarla y proveerle la más alta calidad editorial...iiiporque somos capaces de hacerlo!!!

Estoy orgulloso y sobre todo agradecido por la designación como Editor Invitado de nuestro segundo lanzamiento. A la vez, deseo destacar el trabajo responsable e incansable de los integrantes del Comité Editorial y agradecer a cada uno de los autores que participaron en las diferentes secciones de la revista entregando en tiempo y forma su valioso material.

Nuestra Asociación, su historia y calificada relevancia científica en el mundo entero merecían largamente lo que hoy se ha conseguido con mucho esfuerzo y dedicación. De esta manera, también se ha honrado, como merecían, a los Pioneros de la Cirugía de la Mano Argentina, muchos de ellos nuestros propios mentores, poniendo definitivamente las cosas en su debido lugar...... iiiFelicitaciones a todos por el trabajo!!!!

Dr. MIGUEL CAPOMASSI • miguelcapomassi@gmail.com ID http://orcid.org/0000-0002-4445-662X

Cómo citar este artículo: Capomassi M. Una deuda que saldar. Rev Asoc Argent Ortop Traumatol 2021;86(5):567. https://doi.org/10.15417/issn.1852-7434.2021.86.5.1351 